\title{
Social-Psychological Profiles of Early Adolescents Involved in Bullying Activities
}

\author{
Stelios N. Georgiou* and Panayiotis Stavrinides
}

\author{
Department of Psychology, University of Cyprus, P.O. Box 20537, CY 1678, Nicosia, Cyprus
}

\begin{abstract}
The purpose of the present study was to examine the differences existing between sub-groups of early adolescents involved in bullying activities at school. Specifically, the study aimed at comparing three identified groups (bullies, passive victims and aggressive victims or bully-victims) as well as uninvolved students in terms of a number of indicators of psycho-social adjustment; namely, empathy, impulsivity, hyperactivity, emotional and behavioral problems and pro-social skills. A representative sample of 454 Greek Cypriot students (mean age of 13.4) was selected from seven different public high schools. The participants completed a revised version of the Bullying and Victimization Questionnaire and based on their scores they were classified into one of four, mutually exclusive categories, those of bullies, victims, aggressive victims, and uninvolved. These groups were then compared regarding their mean scores on the Basic Empathy Scale, the Strengths and Difficulties Questionnaire, and the Urgency Subscale. Multiple post-hoc comparisons revealed that the aggressive victims group had the most problematic psycho-social profile. Specifically, aggressive victims were significantly more impulsive, less affectively empathic, and had lower prosocial skills, more behavioural problems and more hyperactivity. The results of the present study show that children and adolescents diagnosed as aggressive victims are at higher risk in a number of psychopathological characteristics that endanger typical development.
\end{abstract}

Keywords: Bullying, impulsivity, empathy, social adjustment.

\section{INTRODUCTION}

Since its introduction in the early 1990's (Olweus, 1993) bullying at school has become a global phenomenon, seriously affecting the lives of a significant minority of children and adolescents (Seals, \& Young, 2003). As such, bullying is now a universal concern (Andreou, 2000; Karatzias, Power, \& Swanson, 2002; Tanaka, 2001). Therefore, identifying the psychosocial profiles of individuals involved in bullying activities remains a high priority because, in addition to its theoretical importance, it can assist in the design and implementation of effective prevention and intervention programs both in the schools and in the wider community.

Depending on their role and involvement in bullying activities, three distinct groups of children have been identified: these are bullies, passive victims and aggressive victims (or bully-victims) (Austin \& Joseph, 1996; Bowers, Smith \& Binney, 1994; Wolke, Woods, Bloomfield \& Karstadt, 2000). Bullies tend to be aggressive and dominant not only at school but also in other aspects of their life (i.e., toward peers, siblings, and adults) (Besag, 1989; Pellegrini, 1998). Empirical studies that have focused on the psychological characteristics of bullies agree that these children are insecure, impulsive and have relatively low levels of

*Address corresponding to this author at the Department of Psychology, University of Cyprus, P.O. Box 20537, CY 1678, Nicosia, Cyprus; Tel: +35722892076; Fax: +357.22892071; E-mail: stege@ucy.ac.cy anxiety (Boulton \& Smith, 1994; Olweus, 1993; Smokowski \& Kopasz, 2005). Further, Kumpulainen and Räsänen (2000) have shown that bullies suffer from externalizing problems such as aggressiveness, attention deficit, hyperactivity and conduct disorders. Additionally, there is evidence suggesting that bullies exhibit also internalizing problems such as depression and anxiety (Kaltiala- Heino, Rimpela, Rantanen, \& Rimpela, 2000). In terms of their relationships with others, bullies tend to manifest low affective empathy (Besag, 1989; Gini, Albiero, Benelli, \& Altoe, 2007; Stavrinides, Georgiou \& Theofanous, 2010). Finally, studies show that, even though bullies portray an image of high self-esteem, they actually tend to feel insecure about themselves (Junger-Tas \& van Kersteren, 1999; Natvig, Albrektsen, \& Qvarnstrom, 2001).

Passive victims on the other hand are more likely to be depressed and anxious (Hawker \& Boulton, 2000; Juvonen, Graham, \& Schuster, 2003; Kaltiala- Heino, Rimpela, Marttunen, Rimpela, \& Rantanen, 1999). They also tend to be insecure, shy, submissive, and introverted (Schwartz, Proctor, \& Chien, 2001). Further, victimization has been associated with low self-esteem, loneliness, and poor peer relationships (Bond, Carlin, Thomas, Rubin, \& Patton, 2001; Crick \& Grotpeter, 1995). Sometimes victims seem to be different from the rest of the children because of an appearance characteristic. Moreover, victims are not popular with peers, which in turn can increase their likelihood to be rejected or victimized. 
The third group, bully/victims or aggressive victims, has been identified more recently as having a distinct profile. These "double-identity" children (Schwartz, Proctor, \& Chien, 2001) share characteristics of both bullies and victims, but their profile seems to be more pathogenic than that of either bullies or victims. Prior studies showed that aggressive victims suffer from severe psychosocial problems (Swearer, Song, Cary, Eagle, \& Mickelson, 2001) and are more temperamental, more different than the typical student and more isolated socially than bullies, victims and non-involved children (Georgiou \& Stavrinides, 2008). Several other studies have shown that aggressive victims have higher levels of depression and anxiety (Arseneault, Walsh, Trzesniewski, Newcombe, Caspi, \& Moffitt, 2006; Schwartz, 2000). Additionally, this group of children has been identified with increased tendencies of reactive aggression and significantly higher rates of attention deficit hyperactivity disorder (Schwartz, 2000). Aggressive victims, unlike bullies, are not popular in school. Juvonen, Graham and Schuster (2003) found that aggressive victims tend to provoke negative interactions with their peers and that they are the most socially avoidant and rejected among their peers. Furthermore, earlier studies have shown that aggressive victims are more likely to have low school achievement (Austin and Joseph, 1996; Georgiou, Stavrinides, \& Kyriakou, 2007; Patterson, 1986; Wolke, Woods, Bloomfield, \& Karstadt, 2000).

Even though the "bully/victim" group seems to be smaller in size (Olweus, 2001), children and adolescents who belong to this group represent an important case since they exhibit both internalizing (Schwartz, 2000) and externalizing problems (Haynie et al., 2001). Furthermore, previous studies have found that there are both short-term and long-term effects in aggressive victims (Headley, 2004; Roland, 2002; Seals \& Young, 2003). Aggressive victims are at high risk of negative developmental outcomes, since they are the group most rejected by their peers and they are more prone to school refusal than any other group involved in bullying (Kumpulainen, Rasanen, Henttonen, Almqvist, Kresanov, \& Linna, 1998). Consequently, they are more likely to drop out of school and develop a series of severe behavioural problems (Parker \& Asher, 1987). Kaltiala- Heino, Rimpela, Rantanen, and Rimpela (2000) indicated that aggressive victims are at greater risk for displaying a range of mental health problems such as internalizing problems and somatic symptoms.
In terms of the long-term effects, aggressive victims seem to have the most serious adjustment difficulties later in their lives. While victims are at greater risk to be depressed and anxious (Bond, Carlin, Thomas, Rubin \& Patton, 2001; Hawker and Boulton, 2000; Olweus, 1993) and bullies are likely to exhibit externalizing problems such as aggressive and antisocial behaviour later in life (Sourander, Helstela, Helenius, \& Piha, 2000), aggressive victims seem to combine all these risks and, therefore, they are in need of closer attention and care as early as possible in their development.

\section{The Present Study}

The present study aimed to examine the differences that may exist between bullies, victims, aggressive victims and uninvolved adolescents in a series of individual attributes identified by prior research as correlates of bullying. These are impulsivity, empathy and social adjustment.

Regarding the relationship between bullying and impulsivity, a number of studies have reported that such positive relationship exists (Jolliffe \& Farrington, 2011; Olweus, 1993; Smokowski \& Kopasz, 2005). Further, a study conducted by Crapanzano, Frick, and Terranova (2010) has shown that aggressive children and adolescents display problems such as impulsivity and bullying. Moreover, Ostrov and Godleski (2009) reported that children that are generally involved in physical aggression had significantly higher levels of impulsivity.

Several studies have consistently shown a negative correlation between peer aggression and empathy (Bryant, 1982; Endresen \& Olweus, 2002; Gini, Albiero, Benelli, \& Altoe, 2007; Mehrabian, Young, \& Sato, 1988; Miller \& Eisenberg, 1988; Stavrinides, Georgiou, \& Theofanous, 2010). Relatively early in the bullying literature, Olweus (1993) observed that bullies tend to have little or no empathy for their victims. On the same issue, a more recent study by Jolliffe and Farrington (2006) has shown that low empathy was significantly related to bullying. Also, prior involvement in bullying decreases empathy in the future (Stavrinides, Georgiou, \& Theofanous, 2010). At a more general level, Miller and Eisenberg's (1988) meta-analysis has shown a consistent negative relationship between antisocial behaviour and lower levels of empathy during childhood.

Finally, previous research has linked bullying to social adjustment problems such as hyperactivity, 
behavioural and emotional problems, and lack of prosocial skills (Gini, 2008; Stavrinides, Georgiou, Nikiforou, \& Kiteri, 2011; Wolke, Woods, Bloomfield, \& Karstadt, 2000). For example, Juvonen, Graham, and Schuster (2003) found that young adolescents who get involved in bullying displayed more school problems than uninvolved children. More specifically, these authors showed that while bullies have increased conduct problems, victims have higher levels of internalizing problems. Additionally, aggressive victims displayed the highest level of conduct, school, and peer relationship difficulties. In the same line, Kumpulainen and Räsänen (2000) have shown that bullying is linked to attention deficit problems, hyperactivity and a wide array of conduct problems. Unlike most of the above studies that have examined only some of the said variables at a time, the present study included all of them in the same design.

Based on the literature outlined above, the following hypotheses were stated:

1. The main hypothesis of the present study was that aggressive victims would have the most pathological profile in comparison to the other two groups (bullies and victims), as well as to the uninvolved adolescents. More specifically, it was hypothesised that bully-victims would be more impulsive, more hyperactive and less empathic than the rest and have more emotional and behavioural problems, while having less prosocial skills.

2. Bullying would have a positive relationship with impulsivity and a negative relationship with empathy and social adjustment.

3. Empathy would have a positive relationship with social adjustment and a negative relationship with impulsivity.

\section{METHOD}

\section{Participants}

The participants were 454 early adolescents attending $7^{\text {th }}$ to $9^{\text {th }}$ grade during the $2010-11$ academic year. Their mean age was 13.4 years (SD = 1.1 years) and they lived in urban $(72 \%)$ and rural $(28 \%)$ areas in Cyprus. Males $(46 \%, \mathrm{n}=210)$ and females $(54 \%, \quad n=244)$ were about equally represented in the sample, which is representative of early adolescent Greek Cypriots.

\section{Instruments}

\section{Revised Bullying and Victimization Questionnaire- $B V Q-R$}

For the purpose of the present study we used a modified version of this instrument, adapted to the local context. It consists of twenty items based on the original questionnaire that was initially constructed by Olweus (1996) and it has been recently used in a number of studies in Cyprus after its translation in Greek language (Georgiou \& Stavrinides, 2008; Georgiou, 2008; Kyriakides, Kaloyirou, \& Lindsay, 2006). In this study, cronbach alpha reliabilities for the bullying and victimization subscales were .81 and .84 respectively. Items from the bullying subscale include statements such as "Other children complain that I hit them", "I want other children to do as I say", "Other children are afraid of me". Items from the victimization subscale on the other hand, include statements such as "Other children constantly tease me and call me names", "Other children exclude me from playing with other children", "Other children have hit me or tried to hit me". Participating adolescents responded to each item on a 5-point Likert-type scale.

\section{Basic Empathy Scale - BES}

The BES is designed by Jolliffe and Farrington (2006) and it examines the degree to which someone understands and feels the emotions of others. The instrument consists of 20 items that evaluate both the cognitive component of empathy (e.g. it is hard for me to understand when my friends are afraid) and the affective component of empathy (e.g. I don't feel sad when I see other people crying). The instrument was recently adapted, translated and back translated to Greek and English with satisfactory psychometric properties (Stavrinides, Georgiou, \& Theofanous, 2010). Also, prior studies have shown quite satisfactory psychometric properties of the instruments with Cronbach alpha for cognitive and for affective empathy. 79 and .85 respectively (Jolliffe \& Farrington, 2006). Our study yields similar reliability coefficients since for the cognitive component the alpha was .79 and for the affective component the alpha was .73. Items from the cognitive empathy include statements such as "I can understand my friend's happiness when she/he does well at something", "I can often understand how people are feeling even before they tell me", "When someone is feeling down" "I can usually understand how they feel". Items from the affective empathy include statements such as "After being with a friend who feels sad about something, I usually feel 
sad", "I get caught up in other people's feeling easily", "I often get swept up in my friend's feelings". Adolescents responded to each item on a 5-point Likert-type scale.

The Urgency Subscale of the Urgency, Lack of Premeditation, Lack of Perseverance, Sensation Seeking Questionnaire (UPPS)

This subscale is one of the four dimensions measured by the UPPS (Whiteside \& Lynam, 2001). The Urgency subscale measures impulsivity based on twelve Likert-type items. These items include statements such as "When I am upset, I act without thinking", "It is hard for me to control my emotions", and "I can't control my impulsivity". In a recent study, Farrington and Jollifee (2011) used the Urgency subscale to measure adolescent impulsivity with satisfactory psychometric properties. In the present study the Impulsivity subscale yielded a cronbach alpha of .82 .

\section{The Strengths and Difficulties Questionnaire (SDQ $-\mathrm{Hel}$ )}

The Strengths and Difficulties Questionnaire - SDQ is a measure of children's psychosocial adjustment (Goodman, 1997). This instrument was initially translated and adapted in Greek language by Mpimpou-Nakou, Stogiannidou, and Kisseoglou (2001). It consists of twenty-five statements measuring adjustment in five basic areas: a. attention and hyperactivity, b. emotional problems, c. prosocial skills, d. behavioural problems and e. peer relationships. A recent study conducted in Cyprus (Stavrinides, Georgiou, Nikiforou, \& Kiteri, 2011) has used the instrument with statistically acceptable psychometric indices. The present study yielded a four factor solution: behavioural problems, emotional problems, hyperactivity, and prosocial skills. All factor alphas were higher than .73 .

\section{Procedures and Data Analysis}

Seven public high schools in Cyprus, five urban and two rural, were randomly selected and their seventh, eighth and ninth grades were included in the sample. All the students in these classes completed batteries of self-reports as described earlier (i.e. the BVQ, the BES, the impulsivity subscale of the UPPS, and the SDQ) in one teaching period. The order of the presented scales was randomized to avoid order bias.

The first aim of the study was to identify the students that could be classified as bullies, victims, aggressive victims, and uninvolved. Thus, a factor analysis with direct oblimin rotation was computed on the data collected from the BVQ in order to identify the factor structure of the instrument. As expected, this analysis extracted a two-factor solution with one factor representing bullying and the second factor representing victimization. The psychometric indices were within acceptable levels since: eigenvalues $>1$, cronbach alphas $>.80$, and $\%$ of total variance explained $=53 \%$. In order to classify the participants into one of the four mutually exclusive categories we computed a composite variable for bullying and victimization. Based on these variables we classified the participants on the following criteria: Participants with a score one standard deviation above the mean on the bullying subscale and one standard deviation below the mean on the victimization subscale were classified as bullies $(n=32)$. Participants with a score one standard deviation above the mean on the victimization subscale and one standard deviation below the mean on the bullying subscale were classified as victims $(n=$ 38). Participants with a score one standard deviation above the mean on both the bullying and the victimization subscale were classified as aggressive victims $(n=14)$. And finally, participants with a score one standard deviation below the mean on both the bullying and the victimization subscale were classified as uninvolved $(n=370)$.

Following this, each of the other three instruments (BES, UPPS, and SDQ) was factor analyzed separately in order to identify the constructs that would be used for comparing the four categories of adolescents based on their bullying experiences. Hence, from the BES, two factors emerged; one representing cognitive empathy and a second representing affective empathy. The SDQ extracted four factors which represent behavioural problems, emotional problems, hyperactivity, and prosocial skills. Further, a single factor was extracted from the Urgency subscale that represents impulsivity. All factor analyses showed acceptable psychometric indices (eigenvalues were all larger than 1 , Cronbach alphas $>.70$, and total variance explained $>40 \%$ ).

\section{RESULTS}

The four groups that were extracted by the procedure outlined above were compared through oneway ANOVA. We used bullying and victimization experience as the independent variable with four levels (i.e. bullies, victims, aggressive victims, and uninvolved). The dependent measures were 
impulsivity, cognitive and affective empathy and social adjustment (hyperactivity, behavioural problems, emotional problems and pro-social skills,). Results of this analysis show that there are significant differences between the four groups of bullying experience on the dependent measures with eta squares ranging from .08 to .18. Scale means, ANOVA indices, and detailed statistical information of this analysis are shown in Tables 1-3.

Table 1: Means and Standard Deviations for the Composite Scores

\begin{tabular}{|c|c|c|}
\hline Construct & Mean & SD \\
\hline \hline Impulsivity & 2.23 & .73 \\
\hline Cognitive Empathy & 3.75 & .70 \\
\hline Affective Empathy & 3.08 & .71 \\
\hline Prosocial Skills & 2.50 & .39 \\
\hline Emotional Problems & 1.46 & .44 \\
\hline Hyperactivity & 1.58 & .52 \\
\hline Behavioural Problems & 1.23 & .34 \\
\hline
\end{tabular}

The multiple comparisons LSD post-hoc analysis (see Table 3) showed that bully-victims were more impulsive than all the other groups at a statistically significant level and the same was true for behavioural problems. They were also more hyperactive, less empathic towards victims and had more emotional problems than the uninvolved students.

In order to investigate in more detail the possible differentiation in behaviour related to bullying due to the dependent measures, we conducted discriminant function analysis with the scores on the BES, UPPS, and SDQ subscales as independent variables, and the categorization of bullies $(\mathrm{N}=23)$, victims $(\mathrm{N}=31)$, aggressive victims $(\mathrm{N}=11)$, and uninvolved $(\mathrm{N}=320)$ as an outcome. The results showed that two discriminant functions were significant. The first function explained the largest percentage of the variance in the data (84.4\%; canonical $R^{2}=.23$ ) and the second function explained $12.9 \%$ of the variance (canonical $R^{2}=.04$ ).

Table 4 presents the functions at group centroids which illustrate how the two functions discriminate

Table 2: One-Way Analysis of Variance and Effect Sizes of Bullying Categories on the Dependent Measures

\begin{tabular}{|c|c|c|c|c|c|c|c|c|}
\hline Scale & Variable & Source & SS & df & MS & $\mathbf{F}$ & $\mathbf{p}$ & $\eta^{2}$ \\
\hline UPPS & Impulsivity & $\begin{array}{c}\text { Between } \\
\text { Group } \\
\text { Within Group }\end{array}$ & $\begin{array}{r}22.53 \\
211.53\end{array}$ & $\begin{array}{c}3 \\
435\end{array}$ & $\begin{array}{l}7.51 \\
.48\end{array}$ & 15.44 & .01 & \\
\hline BES & $\begin{array}{l}\text { Cognitive Empathy } \\
\text { Affective Empathy }\end{array}$ & $\begin{array}{c}\text { Between } \\
\text { Group } \\
\text { Within Group } \\
\text { Between } \\
\text { Group } \\
\text { Within Group }\end{array}$ & $\begin{array}{r}7.51 \\
212.61 \\
13.07 \\
209.66\end{array}$ & $\begin{array}{c}3 \\
436 \\
3 \\
432\end{array}$ & $\begin{array}{l}2.50 \\
.48 \\
.48 \\
4.35 \\
.48\end{array}$ & 5.13 & .01 & .06 \\
\hline $\mathrm{SDQ}$ & $\begin{array}{l}\text { Prosocial Skills } \\
\text { Emotional } \\
\text { Problems } \\
\text { Hyperactivity } \\
\\
\text { Behavioural } \\
\text { Problems }\end{array}$ & $\begin{array}{c}\text { Between } \\
\text { Group } \\
\text { Within Group } \\
\text { Between } \\
\text { Group } \\
\text { Within Group } \\
\text { Between } \\
\text { Group } \\
\text { Within Group } \\
\text { Between } \\
\text { Group } \\
\text { Within Group }\end{array}$ & $\begin{array}{c}6.85 \\
66.61 \\
4.05 \\
87.31 \\
9.01 \\
114.27 \\
9.08 \\
44.44\end{array}$ & $\begin{array}{c}3 \\
443 \\
3 \\
445 \\
3 \\
446 \\
3 \\
447\end{array}$ & $\begin{array}{l}2.28 \\
\\
.15 \\
1.35 \\
19 \\
.19 \\
2.67 \\
.25 \\
.02 \\
3.02 \\
\end{array}$ & 10.68 & .01 & .04 \\
\hline
\end{tabular}


Table 3: Multiple Comparisons (LSD Post - Hoc Analysis) with Means of Each Category on the Dependent Variables

\begin{tabular}{|c|c|c|c|c|}
\hline $\begin{array}{c}\text { Dependent } \\
\text { Variables }\end{array}$ & $\begin{array}{c}\text { Bullies } \\
\text { (a) }\end{array}$ & $\begin{array}{c}\text { Victims } \\
\text { (b) }\end{array}$ & $\begin{array}{c}\text { Aggressive - Victims } \\
\text { (c) }\end{array}$ & $\begin{array}{c}\text { Uninvolved } \\
\text { (d) }\end{array}$ \\
\hline \hline Impulsivity & $2.69^{\mathrm{d}}$ & $2.47^{\mathrm{d}}$ & $3.17^{\mathrm{a}, \mathrm{b}, \mathrm{d}}$ & 2.14 \\
\hline Prosocial Skills & 2.26 & $2.53^{\mathrm{a}, \mathrm{c}}$ & 2.21 & $2.53^{\mathrm{a}, \mathrm{c}}$ \\
\hline Emotional Problems & 1.50 & $1.62^{\mathrm{d}}$ & $1.63^{\mathrm{d}}$ & 1.44 \\
\hline Hyperactivity & $1.83^{\mathrm{d}}$ & $1.76^{\mathrm{d}}$ & $2.07^{\mathrm{d}}$ & 1.52 \\
\hline Behavioural Problems & $1.52^{\mathrm{d}}$ & $1.38^{\mathrm{d}}$ & $1.78^{\mathrm{a}, \mathrm{b}, \mathrm{d}}$ & 3.17 \\
\hline Cognitive Empathy & 3.42 & $3.72^{\mathrm{c}}$ & 3.28 & $3.80^{\mathrm{a}, \mathrm{c}}$ \\
\hline Affective Empathy & 2.61 & $3.09^{\mathrm{a}, \mathrm{c}}$ & 2.47 & $3.15^{\mathrm{a}, \mathrm{c}}$ \\
\hline
\end{tabular}

Note: Mean scores with superscripts indicate significant difference $(p<.05)$ between the particular score and that of the group that the superscript indicates.

between the groups. The first function discriminates well between primarily the aggressive victims and the bullies groups from the victims and uninvolved groups and signifies a positive association of these two groups and high scores on behavioural problems, hyperactivity, and impulsivity subscales, and low scores on cognitive and affective empathy subscales. The second function differentiates the victims group and it indicates high scores on emotional problems (see Table 5).

Table 4: Unstandardized Canonical Discriminant Functions Evaluated at Group Means

\begin{tabular}{|c|c|c|}
\hline \multirow{2}{*}{} & \multicolumn{2}{|c|}{ Discriminant Function } \\
\cline { 2 - 3 } & $\mathbf{1}$ & $\mathbf{2}$ \\
\hline \hline Uninvolved & -.21 & -.03 \\
\hline Victims & .56 & .66 \\
\hline Bullies & 1.08 & -.36 \\
\hline Aggressive Victims & 2.40 & -.17 \\
\hline
\end{tabular}

Table 5: Structure Matrix for the Discriminant Analysis

\begin{tabular}{|c|c|c|}
\hline \multirow{2}{*}{} & \multicolumn{2}{|c|}{ Discriminant Function } \\
\cline { 2 - 3 } & $\mathbf{1}$ & $\mathbf{2}$ \\
\hline \hline Behavioural Problems & $.86^{*}$ & .08 \\
\hline Impulsivity & $.52^{*}$ & .01 \\
\hline Affective empathy & $-.44^{*}$ & .33 \\
\hline Hyperactivity & $.39^{*}$ & .28 \\
\hline Cognitive Empathy & $-.34^{*}$ & .18 \\
\hline Emotional Problems & .10 & $.63^{*}$ \\
\hline Prosocial Skills & -.39 & $.45^{*}$ \\
\hline
\end{tabular}

*Largest absolute correlation between each variable and the disciriminant function.

\section{DISCUSSION}

The main hypothesis of the present study (hypothesis 1) was fully supported by the results. According to these results, aggressive victims seem to have the most psychopathological profile compared to the other two groups - bullies and victims - as well as to the uninvolved adolescents. As can be seen on Table 3, they have higher behavioural problems and higher impulsivity than all three other groups. This supports earlier findings (Gini, 2008; Juvonen, Graham, \& Schuster, 2003; Stavrinides, Georgiou, Nikiforou, \& Kiteri, 2011; Wolke, Woods, Bloomfield, \& Karstadt, 2000). Impulsivity has long been documented to be a robust predictor of a number of developmental difficulties that are related to inability of emotional self regulation, inhibition, and behaviour control. Further, aggressive victims and bullies appear to have less empathy (both cognitive and affective empathy) than either victims or uninvolved adolescents, which shows that they lack the ability to evaluate a situation as harmful or painful to another person. Even more alarming is the finding that bullies and aggressive victims lack the ability to feel sympathy for victims of abuse. The differences in empathy between bullies and aggressive victims on the one hand and victims and uninvolved individuals on the other support previous findings (Endresen \& Olweus, 2002; Gini, Albiero, Benelli, \& Altoe, 2007; Mehrabian, Young, \& Sato, 1988; Miller \& Eisenberg, 1988; Stavrinides, Georgiou, \& Theofanous, 2010). The same gloomy picture continues to appear for bullies and aggressive victims regarding pro-social skills. These two groups have significantly less pro-social skills in comparison to victims and uninvolved individuals. In general, the findings of the present study agree with those of prior research (Arseneault, Walsh, Trzesniewski, 
Newcombe, Caspi, \& Moffitt,, 2006; Georgiou \& Stavrinides, 2008; Schwartz, Proctor, \& Chien, 2001; Swearer, Song, Cary, Eagle, \& Mickelson, 2001) that aggressive victims have the most pathological psychosocial profile compared to any other group that is involved in bullying activity. Moreover, these findings suggest that aggressive victims are more similar to bullies than to victims in terms of social adjustment (i.e. conduct problems and pro-social skills).

Hypothesis 2 was partially supported by the results. In line with earlier research (Crapanzano, Frick, \& Terranova, 2010; Jolliffe \& Farrington, 2011; Ostrov \& Godleski, 2009; Smokowski \& Kopasz, 2005) it was found that bullying is positively related with impulsivity. However, only the affective aspect of empathy had a significant negative relationship with bullying. This is an addition that the present study makes to the existing literature, because most of the earlier studies (for example, Endresen \& Olweus, 2002; Gini, Albiero, Benelli, \& Altoe, 2007; Jolliffe \& Farrington, 2006) do not differentiate between cognitive and affective empathy. Finally, bullying was related to social adjustment in the expected direction (i.e. positively with the negative aspects of it, such as hyperactivity and negatively with the positive ones such as pro-social skills). It is important to note that emotional problems were not related to bullying but to victimization.

Hypothesis 3 was also partially supported by the results. Impulsivity was not related with either cognitive or affective empathy. However, certain aspects of social adjustment were positively related to both cognitive and affective empathy (such as pro-social skills), while other aspects of it (such as behavioural problems) were negatively related to empathy.

\section{Limitations and Contribution of the Present Study}

The present study, in line with standard methodology in this area of research, utilized a number of self report measures in order to assess the indices of personal functioning in the aggressive victim group and to compare this group with other typical categories of adolescents involved in bullying. Even though such methodology is widely used, we recognize the limitations of self-report measures, especially when the topic is emotionally charged (such as victimization) or involves socially unacceptable behaviour (such as bullying activity). Furthermore, a community sample was used for data collection. If a clinical sample were used, then the results might be different, even though, hopefully in the same direction. More importantly, most of the findings of our study were correlational in nature and therefore they claim neither causality nor directionality of effects. More research is needed to address these concerns. Despite these limitations, however, the present study contributes to the relevant literature by identifying important differences in the profiles of adolescents involved in bullying and victimization at school in a number of significant sociopsychological criteria that seem to be related with present and future difficulties in adjustment and well being.

The social-psychological profile of bullies, passive victims and aggressive victims that this study attempted to sketch is very useful, not only for screening purposes but also for the design and implementation of prevention and intervention programs in schools and communities that are struggling with peer aggression problems.

\section{REFERENCES}

Andreou, E. (2000). Bully/victim problems and their association with coping behaviour in conflictual peer interactions among school-age children. Educational Psychology, 21(1), 59-66. http://dx.doi.org/10.1080/01443410125042

Arseneault, L., Walsh, E., Trzesniewski, K., Newcombe, R., Caspi, A., \& Moffitt, T.E. (2006). Bullying victimisation uniquely contributes to adjustment problems in young children: $A$ nationally representative cohort study. Pediatrics, 118, 130138.

http://dx.doi.org/10.1542/peds.2005-2388

Austin, S. \& Joseph, S. (1996). Assessment of bully/victim problems in 8 to 11 year-olds. British Journal of Educational Psychology, 66, 447-456.

http://dx.doi.org/10.1111/j.2044-8279.1996.tb01211.x

Besag, V. E. (1989). Bullies and victims in schools. Milton Keynes: Open University Press.

Bryant, B.K. (1982). An index of empathy for children and adolescents. Child Development, 53, 413-425. http://dx.doi.org/10.2307/1128984

Bond, L., Carlin, J. B., Thomas, L., Rubin, K., \& Patton, G. (2001). Does bullying cause emotional problems? A prospective study of young teenagers. British Medical Journal, 323, 480 484.

http://dx.doi.org/10.1136/bmj.323.7311.480

Boulton, M. J. \& Smith, P. K. (1994). Bully/victim problems in middle school children: Stability, self - perceived competence, peer acceptance. British Journal of Developmental Psychology, 12, 315-325.

http://dx.doi.org/10.1111/j.2044-835X.1994.tb00637.x

Bowers, L., Smith, P. K. and Binney, V. (1994) 'Perceived Family Relationships of Bullies, Victims and Bully/Victims in Middle Childhood', Journal of Social and Personal Relationships, 11, 215-32. http://dx.doi.org/10.1177/0265407594112004

Crapanzano, A. M., Frick, P. J., and Terranova, A. M. (2010) Patterns of Physical and Relational Aggression in a SchoolBased Sample of Boys and Girls. J Abnorm Child Psychol, 38, 433-445. http://dx.doi.org/10.1007/s10802-009-9376-3 
Crick, N. R. \& Gropeter, J. K. (1995). Relational aggression, gender, and social - psychological adjustment. Child Development, $54,1386-1399$.

Endresen, I.M., \& Olweus, D. (2002). Self-reported empathy in Norwegian adolescents: Sex differences, age trends, and relationship to bullying. In A.C. Bohart \& D.J. Stipek (Eds.), Constructive and destructive behaviour: Implications for family, school, and society (pp. 147-165). Washington, DC: American Psychological Association.

Georgiou, S. N. (2008). Bullying and victimization at school: The role of mothers. British Journal of Educational Psychology, 78, 109-125.

http://dx.doi.org/10.1348/000709907X204363

Georgiou, S. N. \& Stavrinides, P. (2008). Bullies, Victims and Bully Victims. Psychosocial Profiles and Attribution Styles. School Psychology International, 29 (5), 574-589. http://dx.doi.org/10.1177/0143034308099202

Georgiou, S. N., Stavrinides, P., \& Kyriakou, M. (2007). Bullying at school: The children's own perception. Scientia Paedagogica Experimentalis, 1, 103-124.

Gini, G. (2008). Associations between bullying behaviour, psychosomatic complaints, emotional and behavioural problems. Journal of Paediatrics and Child Health, 44, 492497.

http://dx.doi.org/10.1111/j.1440-1754.2007.01155.x

Gini, G., Albiero, P., Benelli, B., \& Altoe, G. (2007). Does empathy predict adolescents' bullying and defending behaviour? Aggressive Behaviour, 33, 467-476. http://dx.doi.org/10.1002/ab.20204

Goodman, R. (1997). The Strengths and Difficulties Questionnaire: A research note. Journal of Child Psychology and Psychiatry, 38, 581-586. http://dx.doi.org/10.1111/j.1469-7610.1997.tb01545.x

Hawker, D. S. J. \& Boulton, M. J. (2000). Twenty years' research on peer victimization and psychosocial maladjustment: a meta analytic review of cross - sectional studies. Journal of Child Psychology and Psychiatry, 41(4), 441-455. http://dx.doi.org/10.1111/1469-7610.00629

Haynie, D. L., Nansel, T., Eitel, P., Crump, A. D., Saylor, K., Yu, K. \& Simons - Morton, B. (2001). Bullies, Victims, and Bully/Victims: Distinct Groups of At - Risk Youth. The Journal of Early Adolescence, 21 (1), 29-49. http://dx.doi.org/10.1177/0272431601021001002

Headley, S. (2004). Bullying and violence. Youth studies in Australia, 23(2), 60

Jolliffe, D. \& Farrington, D. P. (2006). Examining the relationship between low empathy and bullying. Aggressive Behaviour, 32 (6), 540-550.

http://dx.doi.org/10.1002/ab.20154

Jolliffe, D. \& Farrington, D. (2011). Is low empathy related to bullying after controlling for individual and social background variables? Journal of Adolescence, 34, 59-71. http://dx.doi.org/10.1016/j.adolescence.2010.02.001

Junger-Tas, J., \& van Kesteren, J. (1999). Bullying and delinquency in a Dutch school population. The Hague: Kugler Publications.

Juvonen, J., Graham, S. \& Schuster, M. A. (2003). Bullying among young adolescents: the Strong, the weak, and the troubled. Pediatrics, 112 (6), 1231-1237.

http://dx.doi.org/10.1542/peds.112.6.1231

Kaltiala-Heino, R., Rimpela, M., Marttunen, M., Rimpela, A., \& Rantanen, P. (1999). Bullying, depression, and suicidal ideation in Finnish adolescents: School survey. British Medical Journal, 319, 348-351. http://dx.doi.org/10.1136/bmj.319.7206.348

Kaltiala - Heino, R., Rimpela, M., Rantanen, P. \& Rimpela, A. (2000). Bullying at School - An Indicator of Adolescents at Risk for Mental Disorders. Journal of Adolescence, 23, 661-674. http://dx.doi.org/10.1006/jado.2000.0351
Karatzias, T., Power, K.G., \& Swanson, V. (2002). Bullying and victimization in Scottish secondary schools: Same or separate entities? Aggressive Behaviour, 28(1), 45-61. http://dx.doi.org/10.1002/ab.90005

Kumpulainen, K., \& Räsänen, E. (2000). Children involved in bullying at elementary school age: Their psychiatric symptoms and deviance in adolescence. An epidemiological sample. Child Abuse \& Neglect, 24, 1567-1577. http://dx.doi.org/10.1016/S0145-2134(00)00210-6

Kumpulainen, K., Rasanen, E., Henttonen, I., Almqvist, F., Kresanov, K., Linna, S., et al. (1998). Bullying and psychiatric symptoms among elementary school-age children. Child Abuse and Neglect, 22, 505-717. http://dx.doi.org/10.1016/S0145-2134(98)00049-0

Kyriakides, L., Kaloyirou, C. \& Lindsay, G. (2006). An analysis of the revised Olweus bully/victim questionnaire using the Rasch measurement model. British Journal of Educational Psychology, 76, 781-801. http://dx.doi.org/10.1348/000709905X53499

Mehrabian, A., Young, A., \& Sato, S. (1988). Emotional empathy and associated individual differences. Current Psychology: Research and Reviews, 7, 221-240. http://dx.doi.org/10.1007/BF02686670

Miller, P.A., \& Eisenberg, N. (1988). The relation of empathy to aggressive and externalizing/ antisocial behaviour. Psychological Bulletin, 103, 324-344. http://dx.doi.org/10.1037/0033-2909.103.3.324

Mpimpou-Nakou, I., Stogiannidou, A., \& Kisseoglou, G. (2001). Strengths and difficulties of school-age children in the family and school context. Psychologia, 8(4), 506-525.

Natvig, G. K., Albrektsen, G. \& Qvarnstrom, U. (2001). School Related Stress Experience as a Risk Factor for Bullying Behaviour. Journal of Youth and Adolescence, 30, 561-575. http://dx.doi.org/10.1023/A:1010448604838

Olweus, D. (1993). Bullies on the playground. In C. Hart (Eds.). Children on playgrounds (pp. 85-128). Albany, NY: SUNY Press.

Olweus, D. (1993). Bullying at School: What we know and what we can do. Cambridge, MA: Blackwell.

Olweus, D. (1996). The Revised Olweus Bully/Victim Questionnaire. Bergen, Norway: Mimeo, Research Center for Health Promotion (HEMIL), University of Bergen.

Olweus, D. (2001). Peer harassment: a critical analysis and some important issues. In Juvonen, J. \& Graham, S. (Eds.). Peer Harassment in School: The Plight of the Vulnerable and Victimized (pp. 105-124). New York: Guilford press.

Ostrov, J. M., \& Godleski, S. A. (2009). Impulsivity-hyperactivity and subtypes of aggression in early childhood: an observational and short-term longitudinal study. Eur Child Adolesc Psychiatry, 18, 477-483. http://dx.doi.org/10.1007/s00787-009-0002-2

Parker, G. J. \& Asher, S. R. (1987). Peer relations and later personal adjustment: Arelow accepted children 'at risk'? Psychological Bulletin, 102, 357-389. http://dx.doi.org/10.1037/0033-2909.102.3.357

Patterson, G. R. (1986). Performance Models for Antisocial Behaviour. American Psychologist, 41, 432-444. http://dx.doi.org/10.1037/0003-066X.41.4.432

Pellegrini, A. D. (1998). Bullies and Victims in School: A Review and Call for Research. Journal of Applied Developmental Psychology, 19 (2), 165-176. http://dx.doi.org/10.1016/S0193-3973(99)80034-3

Roland, E. (2002). Bullying, depressive symptoms and suicidal thoughts. Educational Research, 44, 55-67. http://dx.doi.org/10.1080/00131880110107351

Schwartz, D. (2000). Subtypes of Victims and Aggressors in Children's Peer Groups. Journal of Abnormal Child Psychology, 28, 181-192. http://dx.doi.org/10.1023/A:1005174831561 
Schwartz, D., Proctor, L. J. \& Chien, D. H. (2001). The Aggressive Victim of Bullying: Emotional and Behavioural Dysregulation as a Pathway to Victimization by Peers. In Juvonen, J. \& Graham, S. (Eds.). Peer Harassment in School: The Plight of the Vulnerable and Victimized (pp. 147-174). New York: Guilford Press.

Seals, D., \& Young, J., (2003). Bullying and victimization: Prevalence and relationship to gender, grade level, ethnicity, self-esteem and depression. Adolescence, 38(152), 735-747.

Smokowski, P. R., \& Kopasz, K. H. (2005). Bullying in school: An overview of types, effects, family characteristics, and intervention strategies. Children \& Schools, 27, 101-110. http://dx.doi.org/10.1093/cs/27.2.101

Sourander, A., Helstela, L., Helenius, H. \& Piha, J. (2000). Persistence of Bullying From Childhood to Adolescence Longitudinal 8 - Year Follow - Up Study. Child Abuse and Neglect, 24, 873-881. http://dx.doi.org/10.1016/S0145-2134(00)00146-0

Stavrinides, P., Georgiou, S., \& Theofanous, V. (2010). Bullying and empathy: a short - term longitudinal investigation. Educational Psychology, 30 (7), 793-802. http://dx.doi.org/10.1080/01443410.2010.506004

Stavrinides, P., Georgiou, St., Nikiforou, M, \& Kiteri, E. (2011). Longitudinal investigation of the relationship between bullying and psychosocial adjustment. European Journal of Developmental Psychology, 8(6), 730-743.

http://dx.doi.org/10.1080/17405629.2011.628545

Swearer, S. M., Song, S. Y., Cary, P. T., Eagle, J. W., \& Mickelson, W. T. (2001). Psychosocial correlates in bullying and victimization: The relationship between depression, anxiety, and bully/victim status. Journal of Emotional Abuse, 2, 95121.

http://dx.doi.org/10.1300/J135v02n02 07

Tanaka, T. (2001). The identity formation of the victim of shunning. School Psychology International, 22, 463-476. http://dx.doi.org/10.1177/0143034301224006

Whiteside, S. P. \& Lynam, D. R. (2001). The five factor model and impulsivity: using a structural model of personality to understand impulsivity. Personality and Individual Differences, 30, 669-689. http://dx.doi.org/10.1016/S0191-8869(00)00064-7

Wolke, D., Woods, S., Bloomfield, L. \& Karstadt, L. (2000). The association between direct and relational bullying and behaviour problems among primary school children. Journal of Child Psychology and Psychiatry, 8, 989-1002. http://dx.doi.org/10.1111/1469-7610.00687

DOI: http://dx.doi.org/10.6000/1929-4409.2012.01.5

(C) 2012 Georgiou and Stavrinides; Licensee Lifescience Global.

This is an open access article licensed under the terms of the Creative Commons Attribution Non-Commercial License (http://creativecommons.org/licenses/by-nc/3.0/) which permits unrestricted, non-commercial use, distribution and reproduction in any medium, provided the work is properly cited. 